\title{
ANALISIS UPAYA PAJAK, EFEKTIVITAS, DAN KONTRIBUSI PAJAK DAERAH DI KAWASAN EKONOMI KHUSUS PADA BADAN PENGELOLA PAJAK DAN RETRIBUSI DAERAH KOTA BITUNG
}

\author{
Lusinda Natalya Debora Karo ${ }^{1}$, Lintje Kalangi ${ }^{2}$, Novi Swandari Budiarso ${ }^{3}$ \\ ${ }^{123}$ Jurusan Akuntansi, Fakultas Ekonomi dan Bisnis, Universitas Sam Ratulangi, Jl. Kampus Bahu, Manado \\ 95115, Indonesia \\ E-mail : Lusindakaro@gmail.com
}

\begin{abstract}
Regional autonomy is a law that requires local governments to take care of their own regional needs by utilizing and exploring every potential that exists. One source of regional income is local tax. Local tax is fees paid by society to the state from results of natural resource management and other potential uses for people's welfare. The purpose of this study was to find out about tax effort, effectiveness, contribution and growth of local taxes in the City of Bitung. The research method used is descriptive qualitative. The results of this study indicate that tax efforts by the regional government of Bitung city in 2014-2018 are still in the criteria of "very low", the effectiveness of local tax collection in 2014-2018 is already in the "very effective" criteria and the contribution of the Bitung city tax in 2014, 2016 and 2018 included in the criteria of "good" while in 2015 and 2017 included in the criteria of "good enough" so that the average percentage of local tax contributions to the original income of the city of Bitung included in the criteria of "good".
\end{abstract}

Keywords: Tax effort; effectiveness; contribution; regional government; local tax

\section{PENDAHULUAN}

Negara berkembang adalah negara yang rakyatnya mempunyai tingkat kesejahteraan atau kualitas taraf hidup sedang atau dalam perkembangan, termasuk didalamnya pada bidang sosial, politik, teknologi maupun ekonomi. Indonesia adalah negara berkembang yang memiliki berbagai macam keanekaragaman, baik agama, bahasa, suku, ras, budaya dan sumber daya alam yang melimpah. Keunggulan-keunggulan ini merupakan modal besar bagi Indonesia dalam melaksanakan pembagunan nasional, bagian integral pembangunan nasional adalah pembangunan daerah. Pemerintah daerah harus bekerja keras untuk memanfaatkan sumber daya yang ada agar dapat memenuhi kebutuhan rumah tangga sendiri, apalagi setelah diadakan otonomi daerah. Hak, wewenang, serta kewajiban pemerintah daerah untuk mengurus sendiri masyarakatnya di atur dalam Undang-Undang No. 32 Tahun 2004 tentang Otonomi Daerah Untuk menjalankan otonomi daerah, pemerintah dituntut untuk meningkatkan Pendapatan Asli Daerah (PAD), salah satu sumber PAD adalah Pajak Daerah.

Kawasan Ekonomi Khusus adalah kawasan khusus di Indonesia yang ditetapkan pemerintah untuk menjalankan perekonomian dengan peraturan dan fasilitas khusus. Kota Bitung adalah salah satu kota yang terletak di Provinsi Sulawesi Utara yang menjalankan otonomi daerah dan telah ditetapkan pemerintah sebagai salah satu Kawasan Ekonomi Khusus yang ada di Indonesia. Dengan setiap keberagaman dan potensi yang ada dikota Bitung baik dalam bidang pariwisata, pertanian, perikanan, industri dan dengan adanya KEK Bitung diharapkan dapat menjadi sumber penerimaan yang besar bagi Kota Bitung khususnya dalam penerimaan pajak daerah. 


\section{TINJAUAN PUSTAKA}

Akuntansi. Lubis (2014 : 3) akuntansi adalah suatu proses atau kegiatan yang meliputi proses pengindentifikasian, pengukuran, pencatatan, pengklasifikasian, penguraian, penggabungan, pengikhisarian, dan penyajian data keuangan dasar yang terjadi dari kegiatan operas suatu unit organisasi dengan cara-cara tertentu untuk menghasilkan informasi yang relevan bagi pihak yang berkepentingan. Akuntansi menurut American Accounting Assocation dikutip dari buku akuntansi pajak (Waluyo : 2017) intinya adalah akuntansi sebagi suatu proses identifikasi, pengukuran dan pelaporan informasi ekonomi untuk menilai dan mengambil keputusan yang jelas bagi pemakai informasi tersebut.

Akuntansi Pajak. Muljono (2015 : 2) akuntansi pajak adalah suatu bidang akuntansi yang berkaitan dengan perpajakan dan mengacu pada peraturan perundang-undangan perpajaka yang berlaku. Tumber (2017 : 554) menjelaskan bahwa akuntansi pajak adalah satu bidang akuntansi yang mengkalkulasi, menangani, mencatat, menganalisa dan membuat stretegi perpajakan sehubungan dengan kerjadian-kejadian ekonomi oleh entitas dalam perusahaan maupun dipemerintahan.

Pajak. Berdasarkan Undang-Undang No. 16 Tahun 2009 pajak adalah kontribusi yang diberikan wajib pajak kepada negara yang terutang bersifat memaksa didasarkan pada undang-undang dan tidak memperoleh imbalan secara langsung dipakai untuk keperluan negara dan sebesar-besarnya hanya untuk kemakmuran rakyat.

Pajak Daerah. Mardiasmo (2018 : 14) mejelaskan bahwa pajak daerah adalah kontribusi wajib pajak kepada daerah yang terutang oleh orang pribadi atau badan yang bersifat memaksa berdasarkan undang-undang dan tidak mendapat imbalan secara langsung dan digunakan untuk kepentingan daerah dan rakyatnya.

Dasar Hukum Pajak Daerah. Pajak Daerah diatur dalam Undang-Undang No. 28 Tahun 2009 tentang Pajak Daerah dan Retribusi Daerah (Madiarsmo 2018 : 14). Peraturan Perjakan Kota Bitung diatur dalam Peraturan Daerah Kota Bitung Nomor 1 Tahun 2013 Tentang Perubahan Atas Peraturan Daerah Kota Bitung No. 8 Tahun 2010 tentang Pajak daerah.

Upaya Pajak. Menurut Asmawati et al. (2016 : 37) upaya pajak adalah suatu analisis yang digunakan untuk mengetahui hasil suatu sistem pajak dibandingkan dengan kemampuan membayar pajak suatu daerah. Rumus untuk upaya pajak adalah :

$$
\text { Upaya Pajak }=\frac{\text { Realisasi penerimaan pajak }}{\text { PDRB }} \times 100 \%
$$

Tabel 1. Kriteria Upaya Pajak

\begin{tabular}{cc}
\hline Presentase & Kriteria \\
\hline $76 \%-100 \%$ & Tinggi \\
$51 \%-75 \%$ & Sedang \\
$26 \%-50 \%$ & Rendah \\
$0 \%-25 \%$ & Sangat Rendah \\
\hline
\end{tabular}

Sumber : Asmawati, 2016

Efektivitas. Suhono dan Sulastri (2017 : 241) intinya efektivitas adalah hubungan hasil yang diharapkan dengan hasil yang sesungguhnya tercapai. Pengukuran keberhasilan dalam pencapaian tujuan yang telah ditentukan. Rumus untuk efektivitas adalah :

$$
\text { Efektivitas }=\frac{\text { Realisasi penerimaan pajak }}{\text { Target penerimaan pajak }} \times 100 \%
$$


Tabel 2. Kriteria Efektivitas

\begin{tabular}{cc}
\hline Efektivitas (100\%) & Kriteria \\
\hline$>100 \%$ & Sangat Efektif \\
$90 \%-100 \%$ & Efektif \\
$80 \%-90 \%$ & Cukup Efektif \\
$60-80 \%$ & Kurang Efektif \\
$<60 \%$ & Tidak Efektif \\
\hline
\end{tabular}

Sumber : Koagouw et al. 2018

Kontribusi. Fauziah (2014) menjelaskan kontribusi adalah sumbangan yang diberikan terhadap suatu kegiatan sehingga memberikan dampak yang bisa dirasakan. Menurut Koagouw et al. (2018) intinya kontribusi adalah sesuatu yang diberikan bersamasama dengan pihak lain untuk tujuan biaya dan kerugian ditanggung bersama. Rumus untuk kontribusi adalah :

$$
\text { Kontribusi }=\frac{\text { QXn }}{\text { QYn }} \times 100 \%
$$

Keterangan:

QXn : Jumlah penerimaan pajak daerah

QYn : Jumlah PAD

n : Tahun (periode) tertentu

Tabel 3. Kriteria Kontribusi

\begin{tabular}{cc}
\hline Persentase & Kriteria \\
\hline $0,00-10 \%$ & Sangat Kurang \\
$10-20 \%$ & Kurang \\
$20,10-30 \%$ & Sedang \\
$30,10-40 \%$ & Cukup Baik \\
$40,20-50 \%$ & Baik \\
Diatas $50 \%$ & Sangat Baik \\
\hline
\end{tabular}

Sumber : Koagouw, 2018

Penelitian Terdahulu. Kobandaha dan Wokas (2016) menemukan bahwa tingkat efektivitas pajak reklame sudah efektif dan pajak hotel masih dinilai tidak efektif pada tahun 2015. Kontribusi Pajak Reklame dan Pajak Hotel tahun anggaran 2012-2015 memberikan kontribusi yang baik terhadap PAD. Potensi penerimaan Pajak Reklame dan Pajak Hotel akan mengalami kenaikan pada tahun 2016. Patra (2015) menemukan bahwa berdasarkan peta potensi pajak daerah kota Palopo termasuk kategori Kuadran I yakni potensi tinggi dan upaya pajak tinggi dan berdasarkan Analisis Tipologi Klassen potensi pajak, termasuk kategori Unggulan yakni pertumbuhan pajak daerah tinggi dan konrtibusniya terhadap PAD juga tinggi, maka strategi pengembangan kedepan adalah melalui strategi Promosi dan Ekspansi. Mustoffa (2017) menemukan bahwa: pertama, Pajak Penerangan Jalan memberikan kontribusi besar terhadap Pendapatan Asli Daerah yaitu rata-rata 9,89\%; dan kedua, efektivitas untuk masing-masing pos pajak daerah Kabupaten Ponorogo masuk dalam kategori sangat efektif sampai lebih dari $100 \%$. 


\section{METODE PENELITIAN}

Jenis Data. Data yang digunakan dalam penelitian ini adalah data kualitatif berupa struktur dan sejarah Badan Pengelola Pajak dan Retribusi Daerah Kota Bitung dan hasil wawancara dengan pihak terkait dan data kuantitatif, berupa data target dan realisasi pendapatan daerah, pendapatan asli daerah dan pajak daerah, PDRB, PDRB Perkapita Atas Dasar Harga Berlaku.

Sumber Data. Sumber data yang digunakan dalam penelitian ini adalah data primer ialah wawancara yang dilakukandengan pegawai atau pihak-pihak terkait mengenai pajak daerah maupun produk domestik regional bruto yang ada di Kota Bitung. Dan data sekunder dalam penelitian ini ialah data yang diberikan Badan Pengelola Pajak dan Retribusi Daerah Kota Bitung berupa laporan target dan realisasi keseluruhan pajak daerah Kota Bitung, dan data mengenai laporan produk domestik regional bruto yang didapatkan dari Badan Pusat Statistik Kota Bitung.

Metode Pengumpulan Data. Pertama, penulis melakukan wawancara dengan pihak terkait berhubungan dengan gambaran umum kondisi pajak daerah di Kota Bitung dan kedua melalui dokumentasi laporan target dan realisasi pajak daerah yang diberikan BPPRD, dan laporan PDRB yang diberikan Badan Pusat Statistik Kota Bitung.

Proses Analisis Data. Tahap pertama, peneliti mengumpulkan data-data berupa data target dan realisasi pajak daerah, dan data produk domestik regional bruto kota Bitung. Tahap kedua, peneliti melakukan reduksi data dengan mengelompokkan data-data tersebut kemudian menghitungnya dengan menggunakan rumus upaya pajak, efektivitas, dan kontribusi pajak daerah yang ada. Tahap ketiga, peneliti melakukan penyajian data dengan menggunakan tabel dan grafik. Tahap keempat, merupakan tahap terakhir dimana peneliti menarik kesimpulan dari semua data yang telah diperoleh sebagai hasil dari penelitian antara lain hasil perhitungan antara realisasi pajak daerah dengan produk domestik regional bruto, tingkat efekttivitas, dan juga kontribusi pajak daerah Kota Bitung.

\section{HASIL DAN PEMBAHASAN}

\subsection{Hasil penelitian}

Kota Bitung. Kota Bitung merupakan salah satu pemerintah kota yang ada di Provinsi Sulawesi Utara dengan luas wilayah daratan $304 \mathrm{~km}^{2}$. Sebagian besar wilayah daratan merupakan daerah berombak, berbukit dan gunung. Secara Geografis Kota bitung terletak pada posisi $1^{\circ} 23^{\prime} 23^{\prime \prime}-1^{\circ} 35^{\prime} 39^{\prime}$ ' Lintang Utara dan $125^{\circ} 1^{\prime} 43^{\prime \prime}-125^{\circ} 18^{\prime} 13^{\prime \prime}$ Bujur Timur.

Laporan Realisasi Pajak Daerah Kota Bitung. Tabel 4 menyajikan laporan realisasi pajak daerah kota bitung tahun 2014 sampai dengan tahun 2018.

Tabel 4.Realisasi Pajak Daerah Kota Bitung Tahun 2014 - 2018

\begin{tabular}{|c|c|c|c|c|c|}
\hline \multirow[t]{2}{*}{ Pajak Daerah Kota Bitung } & \multicolumn{5}{|c|}{ Tahun } \\
\hline & $\begin{array}{c}2014 \\
\text { (Rupiah) }\end{array}$ & $\begin{array}{c}2015 \\
\text { (Rupiah) }\end{array}$ & $\begin{array}{c}2016 \\
\text { (Rupiah) }\end{array}$ & $\begin{array}{c}2017 \\
\text { (Rupiah) }\end{array}$ & $\begin{array}{c}2018 \\
\text { (Rupiah) }\end{array}$ \\
\hline Pajak Daerah & 33.493 .759 .019 & 37.360 .100 .376 & 35.463 .283 .256 & 48.071 .594 .414 & 52.752 .813 .115 \\
\hline Pajak Hotel & 2.079 .360 .152 & 1.695 .607 .242 & 2.077 .088 .894 & 1.931 .039 .818 & 2.758 .050 .841 \\
\hline Pajak Restoran & 2.584.314.625 & 2.606.105.374 & 2.623.122.477 & $2.938 .589 .190,60$ & 3.785.236.627 \\
\hline Pajak Hiburan & 345.389 .741 & 286.354 .760 & 353.565 .495 & 493.898 .986 & 589.487 .521 \\
\hline Pajak Reklame & 838.162 .296 & 836.869 .454 & 1.130 .347 .349 & 1.035 .143 .510 & 1.251 .463 .890 \\
\hline Pajak Penerangan Jalan & 12.776 .439 .417 & 12.829 .757 .492 & 12.522 .779 .740 & 14.931.246.641 & 18.498.689.864 \\
\hline Pajak Parkir & 2.610 .000 & 22.932 .900 & 22.981 .500 & 26.482 .900 & 117.160 .298 \\
\hline Pajak Air Tanah & 907.651 .894 & 1.315 .038 .395 & 1.460 .656 .022 & 1.081 .816 .300 & 1.353 .937 .140 \\
\hline Pajak Sarang Burung Walet & 5.300 .000 & 4.100 .000 & 4.100 .000 & 0,00 & 5.000 .000 \\
\hline Pajak Mineral Bukan Logam dan Batuan & 317.167 .164 & 671.637 .571 & 505.573 .490 & 548.834 .697 & 616.491 .040 \\
\hline $\begin{array}{l}\text { Pajak Bumi dan Bangunan Perdesaan dan } \\
\text { Perkotaan }\end{array}$ & 9.537 .670 .447 & 10.837 .187 .754 & 10.113.127.165 & 12.541 .663 .444 & 12.563.328.155 \\
\hline $\begin{array}{l}\text { Bea Perolehan Hak Atas Tanah dan } \\
\text { Bangunan (BPHTB) }\end{array}$ & 4.099.693.283 & 6.254 .509 .434 & 4.649 .941 .160 & 12.542 .878 .928 & 11.213.967.739 \\
\hline
\end{tabular}


Realisasi pajak daerah Kota Bitung pada tahun 2014-2018 selalu menunjukkan peningkatan dari tahun ke tahun. Realisasi penerimaan pajak daerah paling rendah terdapat pada tahun 2014 dengan jumlah sebesar Rp. 33.493.759.019 dan realisasi paling tinggi ada pada tahun 2018 dengan jumlah sebesar Rp. 52.752.813.115. dan terdapat penurunan realisasi penerimaan pajak daerah kota Bitung pada tahun 2016 dikarenakan ada beberapa pajak yang mengalami penurunan maupun tidak mengalami perubahan dari tahun sebelumnya, pajak tersebut ialah pajak penerangan jalan, pajak mineral bukan logam dan batuan, pajak bumi dan bangunan pedesaan dan perkotaan dan bea perolehan hak atas tanah dan bangunan dan pajak pajak srang burung walet yang tidak mengalami perubahan. Pada 2017 jenis pajak yang mengalami penurunan realisasi ialah pajak hotel, pajak reklame, pajak air tanah, dan pajak sarang butung walet yang tidak ada penerimaan ditahun 2017. Tahun 2018 hanya ada dua jenis pajak yang mengalami penurunan dari tahun sebelumnya, pajak tersebut yakni pajak restoran dan bea perolehan ha katas tanah dan bangunan (BPHTB).

Laporan Target Pajak Daerah Kota Bitung. Tabel 5 menyajikan laporan target pajak daerah kota bitung tahun 2014 sampai dengan tahun 2017. Berdasarkan Tabel 5 terlihat jelas bahwa target pajak daerah yang ingin dicapai Kota Bitung pada tahun 2014-2018 selalu meningkat dari tahun ke tahun. Target penerimaan pajak daerah yang ditetapkan pemerintah kota Bitung paling rendah ada pada tahun 2014 dengan jumlah sebesar Rp. 29.370.000.000 dan yang paling besar terdapat pada tahun 2018 dengan jumlah sebesar Rp. 48.098.679.787. Pada tahun 2015-2016 target penerimaan pajak daerah yang ditetapkan pemerintah Kota Bitung sama jumlahnya.

Tabel 5. Target Pajak Daerah Kota Bitung Tahun 2014 - 2017

\begin{tabular}{|c|c|c|c|c|c|}
\hline \multirow[t]{2}{*}{ Pajak Daerah Kota Bitung } & \multicolumn{5}{|c|}{ Tahun } \\
\hline & $\begin{array}{c}2014 \\
\text { (Rupiah) }\end{array}$ & $\begin{array}{c}2015 \\
\text { (Rupiah) }\end{array}$ & $\begin{array}{c}2016 \\
\text { (Rupiah) }\end{array}$ & $\begin{array}{c}2017 \\
\text { (Rupiah) }\end{array}$ & $\begin{array}{c}2018 \\
\text { (Rupiah) }\end{array}$ \\
\hline Pajak Daerah & 29.370 .000 .000 & 32.350 .000 .000 & 32.350 .000 .000 & 36.480 .000 .000 & 48.098 .679 .787 \\
\hline Pajak Hotel & 1.800 .000 .000 & 1.500 .000 .000 & 1.627 .000 .000 & 2.000 .000 .000 & 2.100 .000 .000 \\
\hline Pajak Restoran & 1.900 .000 .000 & 1.950 .000 .000 & 2.150 .000 .000 & 2.550 .000 .000 & 2.700 .000 .000 \\
\hline Pajak Hiburan & 500.000 .000 & 250.000 .000 & 300.000 .000 & 550.000 .000 & 832.500 .000 \\
\hline Pajak Reklame & 850.000 .000 & 800.000 .000 & 750.000 .000 & 900.000 .000 & 1.232 .500 .000 \\
\hline Pajak Penerangan Jalan & 11.500 .000 .000 & 13.630 .000 .000 & 12.500 .000 .000 & 13.000 .000 .000 & 14.500 .000 .000 \\
\hline Pajak Parkir & 10.000 .000 & 15.000 .000 & 20.000 .000 & 35.000 .000 & 55.028 .957 \\
\hline Pajak Air Tanah & 800.000 .000 & 900.000 .000 & 1.100 .000 .000 & 1.440 .000 .000 & 1.340 .000 .000 \\
\hline Pajak Sarang Burung Walet & 10.000 .000 & 5.000 .000 & 3.000 .000 & 5.000 .000 & 5.000 .000 .000 \\
\hline Pajak Mineral Bukan Logam dan Batuan & 300.000 .000 & 300.000 .000 & 300.000 .000 & 500.000 .000 & 550.000 .000 \\
\hline $\begin{array}{l}\text { Pajak Bumi dan Bangunan Perdesaan dan } \\
\text { Perkotaan }\end{array}$ & 8.700 .000 .000 & 9.000 .000 .000 & 10.000 .000 .000 & 10.500 .000 .000 & 13.633 .650 .830 \\
\hline $\begin{array}{l}\text { Bea Perolehan Hak Atas Tanah dan } \\
\text { Bangunan (BPHTB) }\end{array}$ & 3.000 .000 .000 & 4.000 .000 .000 & 3.600 .000 .000 & 5.000 .000 .000 & 11.150 .000 .000 \\
\hline
\end{tabular}

\subsection{Pembahasan}

Upaya Pajak Daerah Kota Bitung. Perhitungan pada Tabel 6 menunjukkan bahwa upaya pajak kota Bitung mengalami kenaikan setiap tahunnya namun terjadi penurunan pada tahun 2016 yang dikarenakan oleh realisasi pajak daerah kota bitung mengalami penurunan dari 37.360.100.376,00 pada tahun 2015 menjadi 35.463.283.256,00 pada tahun 2016 dengan produk domestik regional bruto yang meningkat dari 9.064.842.000.000,35 menjadi 9.537.844.000.000,85. Penurunan realisasi tahun 2016 disebabkan target realisasi yang ditetapkan pemerintah turun namun tetap mencapai dari target yang ditetapkan. 
Tabel 6. Upaya Pajak Penerimaan Pajak Daerah Kota Bitung Tahun 2014 - 2017

\begin{tabular}{clrr}
\hline Tahun & Pajak Daerah & \multicolumn{1}{c}{ PDRB } & Upaya Pajak \\
\hline 2014 & $33.493 .759 .019,00$ & $8.755 .303 .000 .000,69$ & $0.382 \%$ \\
2015 & $37.360 .100 .376,00$ & $9.064 .842 .000 .000,35$ & $0.412 \%$ \\
2016 & $35.463 .283 .256,00$ & $9.537 .844 .000 .000,85$ & $0.371 \%$ \\
2017 & $48.071 .594 .414,72$ & $10.128 .304 .000 .000,46$ & $0.474 \%$ \\
\hline
\end{tabular}

Sumber : Badan Pengelola Pajak dan Retribusi Daerah Kota Bitung

Berdasarkan Gambar 1 terlihat tingkat pencapaian upaya terhadap pajak daerah kota Bitung tahun 2014-2017 mengalami perubahan setiap tahunnya. upaya pajak dikota bitung masih tergolong dalam kriteria "sangat rendah" karena hanya mencapai $0.382 \%$ tahun 2014 , tahun 2015 naik menjadi $0.412 \%$, tahun 2016 turun menjadi $0.371 \%$ dan pada tahun 2017 kembali naik menjadi $0.474 \%$. Upaya pajak/tax effort pajak daerah kota Bitung masih berada dibawah $1 \%$, ini berkaitan dengan seluruh kegiatan perekonomian yang terjadi di kota Bitung dimana kemampuan membayar pajak masyarakat kota Bitung tinggi namun tidak diikuti dengan kesadaran yang tinggi pula dalam membayar pajak. Peningkatan upaya pajak juga sangat dipengaruhi oleh laju inflasi, jumlah penduduk, dan jumlah nilai tambah barang dan jasa atau yang disebut PDRB (Produk Domestik Regional Bruto), sedangkan faktor yang mempengaruhi PDRB antara lain investasi, sumber daya manusia dan perkembangan teknologi.

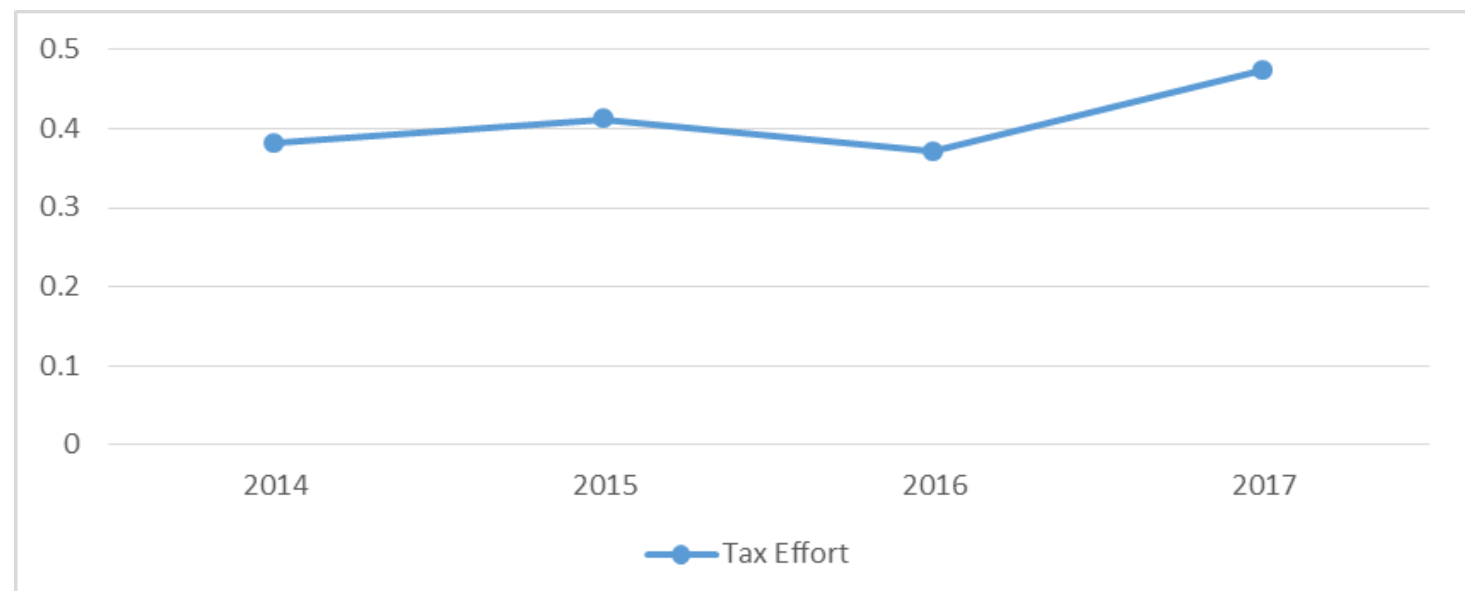

Gamber 1. Grafik Upaya Pajak Penerimaan Pajak Daerah Kota Bitung Tahun 20142017

Kawasan Ekonomi Khusus (KEK) Bitung sangat mempengaruhi tingkat pencapaian upaya pajak dalam pemungutan pajak daerah di Kota Bitung, terlihat dari peningkatan Produk Domestik Regional Bruto (PDRB) atau nilai tambah pada barang dan jasa setiap tahunnya meningkat, yang berarti daya beli masyarakat yang ada kota Bitung sangat tinggi atau tingginya kemampuan masyarakat kota Bitung dalam membayar pajak namun sayangnya ini tidak diikuti dengan penerimaan jumlah realisasi pajak daerah yang cukup besar, atau tidak diikuti dengan kesadaran tinggi masyarakat dalam membayar pajak, hal inilah juga yang menyebabkan upaya pajak kota Bitung masih berada dalam kriteria sangat rendah.

Efektivitas Pajak Daerah Kota Bitung. Terlihat pada tabel 7. Realisasi penerimaan pajak dan target penerimaan pajak daerah kota Bitung terus mengalami peningkatakan kecuali pada tahun 2016 dan 2018. 2016 disebabkan karena target pajak daerah yang ditetapkan pemerintah kota Bitung pada tahun 2016 sama dengan target pajak daerah ditahun 
2015 yakni sebesar Rp. 32.350.000. Tahun 2018 disebabkan oleh selisih antara reaslisasi dan target penerimaan pajak pada tahun ini tidak lebih besar dari tahun 2017.

Tabel 7. Efektivitas Penerimaan Pajak Daerah Kota Bitung Tahun 2014 - 2018

\begin{tabular}{ccrr}
\hline Tahun & Realisasi Pajak Daerah & Target Pajak Daerah & Efektivitas \\
\hline 2014 & $33.493 .759 .019,00$ & $29.370 .000 .000,00$ & $114.04 \%$ \\
2015 & $37.360 .100 .376,00$ & $32.350 .000 .000,00$ & $115.49 \%$ \\
2016 & $35.463 .283 .256,00$ & $32.350 .000 .000,00$ & $109.62 \%$ \\
2017 & $48.071 .594 .414,72$ & $36.480 .000 .000,00$ & $131.77 \%$ \\
2018 & $52.752 .813 .115,00$ & $44.098 .679 .787,00$ & $119.63 \%$ \\
\hline
\end{tabular}

Sumber : Badan Pengelola Pajak dan Retribusi Daerah Kota Bitung.

Gambar 2 menunjukkan efektivitas penerimaan pajak daerah kota Bitung tahun 20142018 mengalami peningkatan maupun penurunan. Tahun 2016 persentasenya turun dari 115.94\% pada 2015 menjadi $109.62 \%$, ditahun 2018 mengalami penurunan dari $131.77 \%$ pada tahun 2017 menjadi 119.63\%. Efektivitas penerimaan pajak daerah kota Bitung paling tinggi berada pada tahun 2018 dengan jumlah persentase 131,77\%. Berdasarkan tabel 2. efektivitas penerimaan pajak daerah kota Bitung sudah termasuk dalam kriteria "sangat efektif", sangat pantas karena realisasi penerimaan pajak daerah setiap tahunnya selalu mencapai atau melebihi dari target pajak daerah yang ditetapkan oleh pemerintah kota Bitung. Hal ini terjadi karena BPPRD sudah menggunakan sistem berbasis jaringan dalam hal ini SIMDA - Pendapatan dan SISMOP, adanya aturan dan ketentuan hukum, kuatnya kebersamaan dan adanya kekompakan dan kerjasama tim antara para pegawai, tidak lepas dari ketegasan dan komitmen pimpinan yang ada, dan juga sarana dan prasarana sudah cukup menunjang.

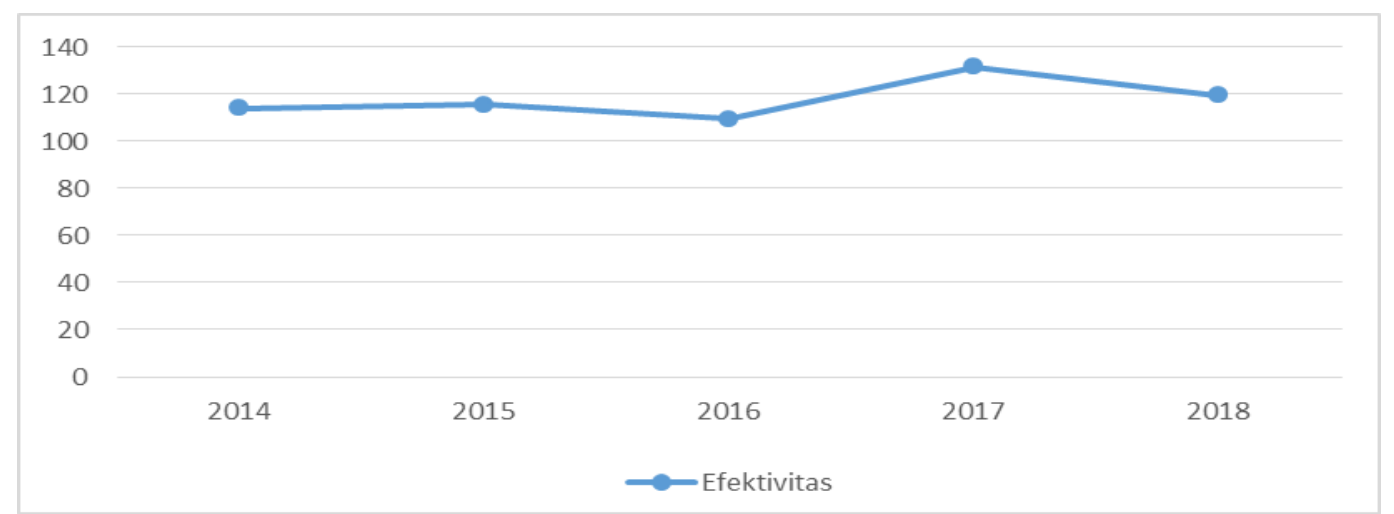

\section{Gambar 2. Grafik Efektivitas Penerimaan Pajak Daerah Kota Bitung Tahun 2014-2018}

Dengan adanya Kawasan Ekonomi Khusus (KEK) Bitung pemerintah bisa membuat peraturan daerah untuk menetapkan sendiri pengurangan, keringan dan pembebasan pajak daerah atau retribusi daerah kepada kepada pelaku usaha/badan usaha di kawasan KEK dan ini diatur dalam Peraturan Pemerintah Republik Indonesia Nomor 96 Tahun 2015 Tentang Fasilitas Dan Kemudahan Di Kawasan Ekonomi Khusus.

Kontribusi Pajak Daerah Kota Bitung. Terlihat dari tabel 8. dan gambar 3. kontribusi pajak daerah terhadap pendapatan asli daerah kota Bitung kenaikan maupun penurunan setiap tahunnya. 2014 : Kontribusi pajak daerah terhadap PAD sebesar 40,10\% dalam kriteria "baik". Tahun 2015 sebesar 36,22\% dan masuk dalam kriteria "cukup baik" hal ini disebabkan oleh penerimaan pendapatan asli daerah kota Bitung pada tahun ini 
meningkat jauh dan tidak diikuti dengan peningkatan realisasi penerimaan pajak daerah yang cukup signifikan dan hal yang sama terjadi pada tahun 2017.

Tabel 8. Kontribusi penerimaan pajak daerah Kota Bitung tahun 2014-2018

\begin{tabular}{ccrr}
\hline Tahun & Pajak Daerah & Pendapatan Asli Daerah & \multicolumn{1}{c}{ Kontribusi } \\
\hline 2014 & $33.493 .759 .019,00$ & $83.520 .151 .103,00$ & $40.10 \%$ \\
2015 & $37.360 .100 .376,00$ & $103.133 .530 .054,30$ & $36.22 \%$ \\
2016 & $35.463 .283 .256,00$ & 82.927 .096 .690 .63 & $42.76 \%$ \\
2017 & $48.071 .594 .414,72$ & $122.816 .219 .057,04$ & $39.14 \%$ \\
2018 & $52.752 .813 .115,00$ & $109.788 .026 .417,14$ & $48.05 \%$ \\
\hline
\end{tabular}

Sumber : Badan Pengelola Pajak dan Retribusi Daerah Kota Bitung.

Tahun 2016 sebesar $42.76 \%$ kembali masuk dalam kriteria "baik" hal ini terjadi karena total realisasi pendapatan asli daerah tidak melebihi dari target yang tentukan, sedangkan untuk pajak daerah sendiri target penerimaannya masih tetap sama dari tahun kemarin. Tahun 2018 kontribusi pajak daerah terhadap PAD sebesar 48.05\% dan masuk dalam kriteria "baik" Faktor yang mempengaruhi naik turunnya kontribusi ini adalah kurang adanya keterlibatan dan kerjasama antara dinas yang ada di Kota Bitung, faktor lainnya yaitu faktor geografis, cuaca iklim dan jauhnya tempat tinggal wajib pajak.

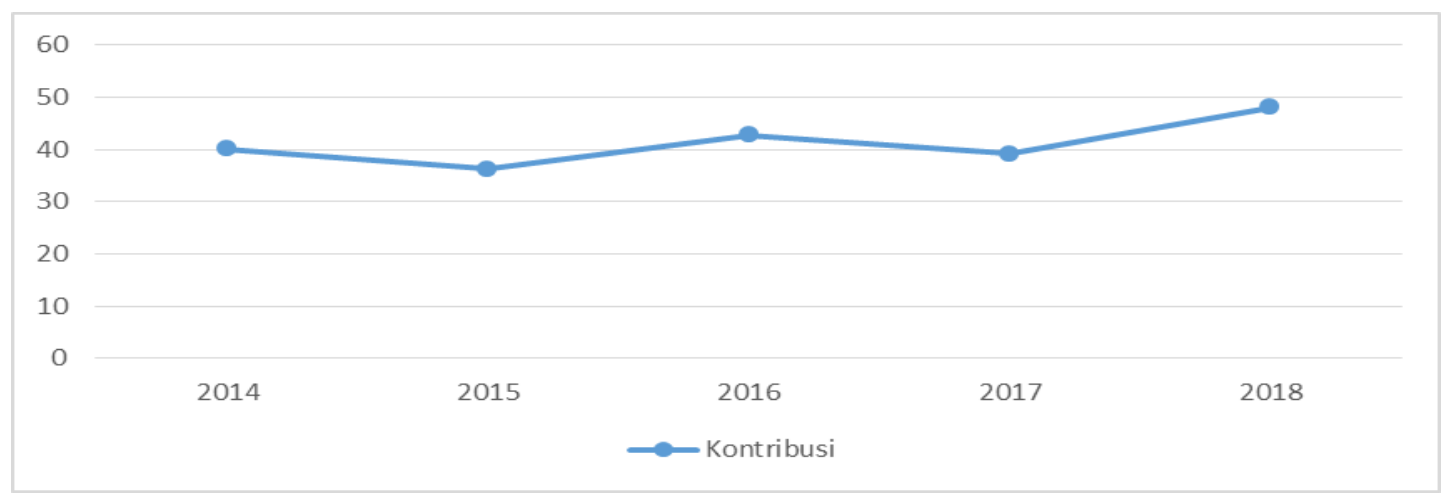

Gambar 3. Grafik Kontribusi Penerimaan Pajak Daerah Kota Bitung Tahun 2014-2018

\section{KESIMPULAN DAN SARAN}

\subsection{Kesimpulan}

Berdasarkan hasil penelitian yang telah dilakukan dapat disimpulkan bahwa:

1. Tingkat pencapaian upaya pajak dalam pemungutan pajak daerah di Kawasan Ekonomi Khusus Kota Bitung tahun 2014-2017 masih tergolong "sangat rendah" karena masih bawah 1\%. KEK Bitung sangat mempengaruhi peningkatan jumlah PDRB.

2. Tingkat pencapaian efektivitas pemungutan pajak daerah di Kawasan Ekonomi Khusus Kota Bitung tahun 2014-2018 masuk dalam kriteria "sangat efektif" dengan persentase selalu melebihi $100 \%$.

3. Kontribusi Pajak Daerah Terhadap Pendapatan Asli Daerah di Kawasan Ekonomi Khusus Kota Bitung tahun 2014-2018 masuk dalam kriteria "baik" karena kontribusinya selalu melebihi $40 \%$, namun kontribusnya belum mencapai lebih dari $50 \%$.

\subsection{Saran}

1. Badan Pengelola Pajak dan Retribusi Daerah bersama dengan pemerintah Kota Bitung harus terus menggali dan juga menjangkau dan memanfaatkan potensi-potensi yang ada dikota Bitung, apalagi dengan adanya KEK Bitung dan perlu dilakukan kajian ulang 
mengenai sanksi yang diberikan kepada wajib pajak, agar benar-benar membuat wajib pajak kapok dan menjadi taat aturan.

2. Badan Pengelola Pajak dan Retribusi Daerah harus terus mempertahankan dan juga meningkatkan integritas dalam menjalankan tugas dan tanggungjawabnya dalam pemungutan pajak daerah kota Bitung.

3. Badan Pengelola Pajak dan Retribusi Daerah Kota Bitung harus mampu menjangkau wajib pajak yang berada jauh dari pusat kota maupun yang tinggal dipulau dengan sering mengadakan sosialisasi baik secara langsung maupun menggunakan media sosial kepada masyarakat tentang pentingnya membayar pajak, dan perlu adanya evaluasi dan perbaikan ulang tentang koordinasi antara dinas yang berkaitan

\section{DAFTAR PUSTAKA}

Asmawati, D., Elvandari, N. \& Baihaqi. (2016). Analisis tax effort, efektivitas, kontribusi dan pertumbuhan pajak daerah Kota Bengkulu Tahun 2011-2014. Jurnal Akuntansi 4(1), 33-50. https://doi.org/10.33369/j.akuntansi.6.1.35-52

Fauziah, I. (2014). Analisis kontribusi penerimaan pajak daerah sebagai salah satu Pendapatan Asli Daerah (PAD) Kabupaten Malang (Studi pada Dinas Pendapatan Pengelolaan Keuangan dan Aset Kabupaten Malang). Jurnal Mahasiswa Perpajakan. 3(1), $1-7$. http://perpajakan.studentjournal.ub.ac.id/index.php/perpajakan/article/view/70/63.

Koagouw, B., Karamoy, H., \& Lambey, R. (2018). Analisis efektivitas dan kontribusi Bea Perolehan Hak atas Tanah dan Bangunan terhadap pajak daerah pada Badan Pengelola Pajak dan Retribusi Daerah Kabupaten Minahasa. Going Concern : Jurnal Riset Akuntansi, 13(04), 372-380. https://doi.org/10.32400/gc.13.04.21160.2018

Kobandaha, R., \& Wokas, H. (2016). Analisis efektivitas, kontribusi dan potensi pajak reklame dan pajak hotel terhadap Pendapatan Asli Daerah Kota Kotamobagu. Jurnal EMBA, $\quad 4(1)$, https://ejournal.unsrat.ac.id/index.php/article/view/123/11943 1461-1472.

Lubis, A. I. (2014). Akuntansi Keperilakuan. Edisi 2. Jakarta: Salemba Empat.

Mardiasmo, 2018. Perpajakan. Edisi Terbaru 2018. Yogyakarta: Penerbit Andi.

Muljono, D. (2015). Hukum Pajak. Yogyakarta: Penerbit Andi.

Mustoffa, A. F. (2017). Kontribusi dan efektifitas pajak daerah Kabupaten Ponorogo. Jurnal Akuntansi dan Pendidikan, 7(1), 1-14. http://doi.org/10.25273/jap.v7i1.1634

Patra, A. (2015). Analisis upaya pajak daerah (tax effort) dalam mendukung peningkatan PAD Kota Palopo. Prosiding Seminar Nasional, 03(1), 72-81. http://docplayer.info/80996393-Analisis-upaya-pajak-daerah-tax-effort-dalammendukung-peningkatan-pad-kota-palopo.html

Peraturan Daerah Kota Bitung Nomor 1 Tahun 2013 Tentang Perubahan Atas Peraturan Daerah Kota Bitung Nomor 8 Tahun 2010 Tentang Pajak Daerah.

Suhono, \& Sulastri, E. M. (2017). Analisis Kontribusi Dan Efektivitas Pajak Daerah Sebagai Sumber Pendapatan Asli Daerah Kabupaten Karawang. Accounthink : Journal of Accounting and Finance, 2(1), 247-259. https://journal.unsika.ac.id/index.php/accounthink/article/view/729/638

Undang-Undang Nomor 32 Tahun 2004 tentang Pemerintah Daerah.

Undang-Undang Nomor 16 Tahun 2009 tentang Perubahan Keempat Undang-Undang Nomor 6 Tahun 1983 tentang Ketentuan Umum dan Tatacara Perpajakan

Undang-Undang Nomor 28 Tahun 2009 tentang Pajak Daerah dan Retribusi Daerah.

Waluyo, 2017. Akuntansi Pajak. Edisi 6. Jakarta: Salemba Empat. 